\title{
Solar Energy Utilization for Bagasse drying through Hollow Shape Slat Chain Conveyor
}

\author{
Amit Kumar ${ }^{1}$, Anurag Singh ${ }^{2}$, Dr. Raj Mani ${ }^{3}$ \\ ${ }^{1}$ M. Tech. Scholar, R.M.L Avadh University, Faizabad (U.P.), India \\ ${ }^{2}$ Assistant Professor, R.M.L Avadh University, Faizabad (U.P.), India \\ Assistant Professor, ND University of Agriculture and Technology, Ayodhya, Uttar Pradesh, India
}

\begin{abstract}
The utilization of bagasse as a fuel in sugar cane industry is well known. The moisture content offresh bagasse is relatively high which lowers the total heat available from bagasse and effects its combustion efficiency. Therefore bagassse drying has become a necessity in order to improve its combustion efficiency. In the present work, the use of parabolic trough solar collector to generate the heat steam from working fluid is studied. A working fluid is heated up to $398^{\circ} \mathrm{C}$ as it circulate through the receiver pipes and return to the heat exchanger. Hence, the working fluid circulate through the pipes so it transfers heat to low temperature, low pressure steam, received from Multi Effect Evaporator outlet to generate high temperature steam. The high temperature steam from heat exchanger move towards hollow shape slat chain conveyor to drying bagasse. Heat requirement, Number of transfer unit and heat capacity ratio were calculated as $238662 \mathrm{KWh}, 72372 \mathrm{~W}$ and 0.5 respectively. Thickness of upper surface of hollow shaped slat chain conveyor made from steel was found as $1 \mathrm{~cm}$, through which the moisture reduction ratio as 0.20 was found in the 8min drying of bagasse.
\end{abstract}

Keywords- bagasse, sugar cane industry, gravimetric method.

\section{INTRODUCTION}

The study area located in the eastern plain zone of Uttar Pradesh, India. Barabanki district of Uttar Pradesh has 3.6 per cent cultivated area for sugarcane production. The total area of sugarcane production is 9.6 thousand hectares with an average productivity as 53693 $\mathrm{kg} / \mathrm{hectare}$ as per Agriculture contingency plan for Barabanki district of Uttar Pradesh. The Dhampur sugar mill Rauzagaon located in this district has good connectivity with national highway (NH-28) at $27^{\circ} 19^{\prime}$ and 26 $30^{\prime}$ ' north latitude and $80^{\circ} 05^{\prime}$ and $81^{\circ} 51^{\prime}$ east longitude. This mill has crushing capacity of 45,500 metric tonnes per day capacity to produce 1700 metric tonnes refined sugar/day. This mill is the first in India to manufacture surplus refined sugar.

Bagasse is the residual fibre that remains after the crushing of sugarcane. Bagasse represent 12 per cent moisture of the total sugarcane mass. As observed, the average moisture content in the bagassse is between 50.18 per cent to 52.30 per cent with this percentage of moisture content the efficiency of boiler is about 70.86 per cent. Since the objective of this paper is to dry the wet bagasse by using newly designed hollow shaped slat chain conveyor to improve the efficiency of boiler, so that the cost of sugar production get reduced.

\section{MATERIAL AND METHOD}

The moisture content just after crushing of sugarcane in the bagasse has calculated by gravimetric method on dry weight basis. For drying its moisture. Parabolic solar collector heats a working fluid upto the temperature of $398^{\circ} \mathrm{C}$, which circulates through the receiver pipe and returns to heat exchanger. The high temperature steam from heat exchanger moves toward hollow shape slat chain conveyor to dry the wet bagasse. Heat conduction and convection takes place between steam and conveyor bed. Hence, top surface of conveyor bed gets high temperature. As soon as bagasse moves on conveyor surface it receive heat and looses moisture upto the inlet of boiler furnace.

Heat Capacities of working fluid and steam were calculated by multiplying mass of working fluid to the specific heat of working fluid. Similarly mass of steam to the specific heat of steam, respectively. The circulating heat capacity ratio, obtained by dividing the heat capacity ratio of steam to the working fluid. The number of transfer unit (NTU) is obtained by dividing the product of heat transfer coefficient and surface are of conveyor to the heat capacity ratio of steam. With the help of NTU curves effectiveness of heat exchanger was found which is multiplied by maximum heat transfer to get the effectiveness of the heat exchanger used in the study. From the graph of drying Kinetics, the moisture ratio reduction is calculated for a particular time.

\section{RESULT AND DISCUSSION}

The crushing capacity of the mill is $45500 \mathrm{MT} /$ day and production of bagasse at $12 \%$ was found as 5460 MT/day. Wet sampled weight of bagasse taken, found as 
$253.17 \mathrm{gm}$ and after drying it has found as $172.68 \mathrm{gm}$. For this sample, moisture content obtained as $47.12 \%$ in the bagasse. M. Manickavasagam, et. al. (2018) also used gravimetric method for moisture content determination. Time consumption was normally 6-8 hour. They found 46 to 52 per cent moisture content in various samples collected and estimated in their experiments. These values are very much in corroboration to the results of moisture content calculated under study. The heat requirement for bagasse drying is calculated by the formula,

$\mathrm{Q}=\mathrm{m} \times \mathrm{c} \times \delta \mathrm{t}$

where, $\mathrm{m}=$ mass of bagasse in $\mathrm{Kg}$.

$\mathrm{c}=$ Specific heat in $\mathrm{KJ} / \mathrm{Kg}{ }^{\circ} \mathrm{C}$

$\delta \mathrm{t}=$ Change in temperature of working fluid and outlet temperature of MEE.

Hence, $\mathrm{Q}=45500 \times 1000 \times 0.548 \times\left(400^{\circ} \mathrm{C}-57^{\circ} \mathrm{C}\right)$

$455 \times 1065 \times 0.548 \times 343^{\circ} \mathrm{C}$

$=2386662 \mathrm{KWh}$.

Heat capacity of hot fluid $\left(\mathrm{C}_{\mathrm{h}}\right)$ and steam $\left(\mathrm{C}_{\mathrm{c}}\right)$ respectively calculated as

$\mathrm{Ch}=\mathrm{m}_{\text {fh }} \times \mathrm{C}_{\mathrm{ph}}=100 \times 4.277=427.70=$ Abbrebiated as

Cmax

$\mathrm{Cc}=\mathrm{m}_{\mathrm{fc}} \times \mathrm{C}_{\mathrm{pc}}=100 \times 2.110=211.00=$ Abbrebiated as

Cmin

Where,

$m_{\text {th }}$ - Mass flow rate of working fluid of PTC.

$\mathrm{C}_{\mathrm{ph}}$ - Specific heat of working fluid of PTC.

$m_{\mathfrak{f}}$ - Mass flow rate of steam received from outlet of

MEE.

$\mathrm{C}_{\mathrm{pc}}$ - Specific heat of steam received from outlet of MEE.

Heat capacity ratio $=211 / 427.70=0.5$, and

$\mathrm{NTU}=211\left(400^{\circ} \mathrm{C}-57^{\circ} \mathrm{C}\right)=72373 \mathrm{~W}$, and

Effectiveness of Counter flow heat exchanger, obtained

from effectiveness - NTU Curves as heat exchanger duty

$=$ effectiveness of heat exchanger $\mathrm{x}$ maximu $\mathrm{m}$ heat

transfer

$=1 \times 72373$

$=72373 \mathrm{~kW}$

Now, average heat transfer coefficient $(\mathrm{H})$, calculated by $-$

$\mathrm{H}=0.036(\mathrm{k} / \mathrm{L})(\mathrm{Re})^{4 / 5}(\mathrm{Pr})^{1 / 3}$

$=0.036\left(6.00616 \times 10^{\wedge}-3\right)\left(2.128 \times 10^{\wedge} 8\right)^{4 / 5}(9.9768 \times$

$\left.10^{\wedge}-3\right)^{1 / 3}$

$=213.936 \mathrm{~W} / \mathrm{m}^{2} \mathrm{~K}$

and from equation, $\mathrm{Q}=\mathrm{H} \times \mathrm{A} \times\left(\mathrm{T}_{\mathrm{c} 2}-\mathrm{T}_{\mathrm{sfl}}\right)$

$72373=213.936 \times 60\left(400-\mathrm{T}_{\mathrm{sfl}}\right)$

$\mathrm{T}_{\mathrm{sfl}}=394.36{ }^{\circ} \mathrm{C}$

Where,

$\mathrm{T}_{\mathrm{c} 2}=$ Temperature of steam.

$\mathrm{T}_{\text {sfl }}=$ Temperature at the lower surface of bed.

Temperature of upper surface depends upon the thermal conductivity of material, used to made for conveyor bed. Steel has taken for conveyor bed which gives the temperature of top surface of conveyor as $394.11^{\circ} \mathrm{C}$. From the graph of drying Kinetics of sugarcane bagasse at different temperature, in 8 min duration the moisture reduction ratio found as 0.20 . The temperature of conveyor bed controlled by varying mass flow rate of steam flow and by mounting pressure releasing valves at the inlet of conveyor.

\section{CONCLUSION}

The first conclusion is that a significant part of the demand can be covered with a small field. The parabolic trough collectors have the area as $174715 \mathrm{Sqm}$ for collecting solar energy. The hot pressurized water, as working fluid taken in the study. Results of the study support the recent motivation. The aim of the introduction of dryer was to reduce moisture content in wet bagasse in order to improve boiler efficiency and reduce device costs. The obtained results show clearly that these aim were succeeded. The boiler efficiency was improved from 69 per cent to 81 per cent.

\section{REFERENCES}

[1] Ajeet Banasode et. al.; "Design and Analysis of Bagasse Dryer to Recovery Energy of Water Tube Boiler in a Sugar Factory"; Intl. J. of Innovative Technology and Research, Vol. No. 5 , Issue No. 4, June - July 2017; pp : 6645-6651.

[2] Joyce Matia Gomes d a costa, Jefferson Luiz Gomes Correa, Bruno Elyeser Fonseca, Fl avio Maria Borem and Soraia videla Borges; (2014) "Drying and Isotherms of sugarcane Bagasse" Engenheria NA Agricultura vicasa- MG; pp : 128-142.

[3] Manickavasagam, M. Elango, T.; Siddharth, S; Senthil kumar, T; and Elangovan, K (2018); "Methods for determining moisture content in bagasse of sugarcane using microwave oven"; Intl. J. Adv. Res. mgt, Arch, Tech. \& Engg. (IJARNATE); V -4 (8); ISSN (Print): 2454 -9762; pp : 149-152.

[4] Mishra,A.N.; (2018), "Materoleogical parameters in eastern plain zone of Uttar - Pradesh" NDUAT, Faizabad.

[5] Shital Phadkari;Shweta Patil and S.U. Deokar (2017); "Design and Modeling of solar bagasse dryer; Intl. Conf. Idea, Impact and Invo. in Mech. Engg. (ICHIME); pp: 661-665.

[6] Cerqueira, A., Balduíno, A., \& Lima, D. (2018). Feasibility Analysis of the Solar Energy System in Civil Construction. International Journal of Advanced Engineering Research And Science, 5(6), 39-44. doi: 10.22161/ijaers.5.6.7

[7] Sugar Industry report, Govt. of India; Dec. -2004. 